\title{
MICROFINANCE AND THE FIGHT AGAINST POVERTY IN THE DEMOCRATIC REPUBLIC OF CONGO
}

\author{
PhD. Marcel Kamba-Kibatshi ${ }^{1 *}$
}

${ }^{* 1}$ Department of Economics, Institute of Sociology, Faculty of Historical and Social Sciences, University Cardinal Stefan Wyszyński in Warsaw, 47, Zelenskiego Street, 64-920 Piła, Poland. Phone number +48/694 880827 and e-mail: marcel_kamba@interia.pl

\section{*Corresponding Author: -}

E-mail: marcel_kamba@interia.pl

\begin{abstract}
: -
Studying both the Congolese and Cameroonian cases, this article shows that beyond some normalisation, microfinance prompts some very distinctive ways of appropriation. The authors wonder about the role of states as "ferrymen" of the word "microfinance". They question the ability and the freedom of organisations and local authorities to put in place microfinance schemes. In a first section, the paper underlines the normative conception going with the term "microfinance". In a second and third sections it discusses the circulation of the term and the manufacture of practices in the Democratic Republic of Congo and Cameroon. It comes to the conclusion that despite the eventual enforcement of practices and social norms, microfinance has to acclimatize itself to divergent social, political and even religious practices.
\end{abstract}

Key words: micro credit-microfinance - financial crisis

JEL Code : G 29-0 16-F 30

\section{(ㄷ) (오 (1)}




\section{INTRODUCTION}

At the beginning of the third millennium when the powers of man have never been so powerful and so extensive, natura hazards are still relevant. The debates on Poverty, the continuing degradation of the environment, Democracy and Sustainable Developpment Express concerns about the future of Africa. Poverty is a cause and a consequence of the continuing degradation of the environment. It exacerbates his degradation by forcing poor people to exploit marginal lands or deplete fisheries ressources In a desperate struggle to survive. Although poverty has previously been defined by income, a consensus is emerging today that it encompasses a serie sof deprivations including lackof Access to natura ressources, heath care and vulnerability to disasters. In fact, to the vulnerabilities that come under the political or the economy of the States are added individual and societal vulnerabilities linked to a sum of precariousness such as raindependent forming systems, a habitat site on spacer declared in constructible. Because they are flooded or expose to landslides, menager economic, food and sanitarny resources, poor health. Nowadays, if the theme of the fight against poverty and sustainable developpment is becoming a political and scientific discourse, it is important In the microfinance sector not to be limited to a strictly economic, political or social approach, but much more to the provision of a financial product package to poor familie to help them conduct productive or income-generating activities.

\section{Problematic}

The Democratic Republic of Congo is a country whose economic, political and social structures do not meet the basic needs of the population. It is characterized mainly by massive poverty and low integration into the world economy, hence its classification among developing countries. As a result, developing countries are characterized by many problems such as undernourishment, the vulnerability of its population and low investment in human capital (education, health). This observation is observed despite the fact that these countries contain in their breasts human and natural potentialities to improve their living conditions. Strong of this reality, the popular classes, in rural or urban environment, thus have mainly recourse to the endogenous sector, created by the populations without external intervention. This is the world of individual lenders, with zero or so-called "usurious interest rates", guards, simple or complex tontines with auction, traveling bankers, solidarity funds, investor clubs, ... It's an imaginative world, adapted to socio-economic and cultural constraints, but with limited financial resources, it can be very expensive and risky. Note, however, that the fight against poverty in the Democratic Republic of Congo may be possible by consolidating macroeconomic stability and growth, supporting community dynamics, improving access to social services and reducing vulnerability.

Indeed, the Democratic Republic of Congo, a country with a poorly developed economy, should promote the promotion of entrepreneurship in order to enable it to revalue the capacities of its population and to make more urgent the need to promote alternative structures of financing that can mobilize small savings, provide credit in rural and disadvantaged urban areas, and create conditions for gradual integration. So let's look at a sector that can act as an accelerating lever to achieve one of the millennium goals that is nothing more than the reduction of poverty. Microfinance is one of the possible solutions to achieve this objective, insofar as it has for mission, the collection of the savings, the hiring of safe, the actions of formation, the operations of leasing and the leasing. providing micro-credit to poor families to help them carry out productive or income generating activities.

These families are generally referred to as micro-entrepreneurs and most of these microentrepreneurs work in the informal or informal sector. Hence the emergence of micro finance, which appears as an intermediate sector able to meet the important needs of quality financial services, savings, loans and insurance, for the majority of those who do not have real access to the banking sector and whose number goes well beyond of those who can be called "poor". Microfinance is aimed not only at the "extremely poor", those who live on less than one (1) dollar (USD) a day, but also, and sometimes mainly, at small producers, while the amounts lent or saved remain limited. The credits are for the most part less than one thousand dollars. In the frame of our scientific work, it is question to understand: „The contribution of the microfinance in the process of the fight against poverty in the Democratic Republic of the Congo ".

\section{Hypothesis of work}

As a development tool, microfinance is not limited to microcredit for the poor, but rather to the provision of a set of financial and non-financial products to all those who are excluded from the traditional financial system. In addition, the provision of non-financial services such as microentrepreneur training and health and hygiene education courses gives microfinance institutions a role in social intermediation. In this regard, the report of the microfinance summit campaign states that: "microfinance programs can become more important for other desirable social developments". In other words, the diversity of services and products brought by microfinance leads to the improvement of the standard of living of the entire population and, consequently, to possible development. Thus, the answer that is the hypothesis of our proposed study to the concern mentioned above can be summarized as follows: "Microfinance is an effective weapon in the fight against poverty and through it, integral development is possible" .

\section{Interest and Choice of Subject}

The choice made on this subject is influenced by the economic instability experienced by the Democratic Republic of Congo on the poor living conditions, vulnerability, malnutrition and poverty that prevails despite all the human and natural potential contained in this economic instability. To this end, the interest in this theme of scientific research is to enable those interested in the problems of prosperity of the nation and possibly readers to grasp the contribution of microfinance in the process of poverty alleviation. Democratic Republic of Congo. We hope that our work can serve as a basis for future surveys on the creation of microfinance institutions through which economic development is possible in the country. 


\section{Operating environment}

It is the application of scientific knowledge or all the processes in the processing and analysis of data or information. Techniques are the set of methods that allow a researcher to gather original information or second hands on a subject. It is therefore understood as any means that enables the researcher to acquire and process the data he needs to understand or explain a phenomenon or subject of study. We distinguished two great blocks of techniques namely the living techniques and the documentary techniques. We used historical and analytical methods.

- Historical methods: Consist of gathering, ordering, hierarchizing around a singular phenomenon a plurality of the facts by establishing the links between the studied fact and the situations which are annexed to it, anterior and posterior.

- The analytical metod: It makes it possible to compose and examine the components of the problem through various encrypted elements in possession.

- Documentary techniques: These are those that take the form of an indirect observation, in that it concerns the study and analysis of written documents including published works, archives, memoirs and unpublished documents. This technique has made it possible, by consulting the different works, to collect data relating to the subject under study.

- Living techniques: They are also called free interviewing: an interview is a collection of data that consists of a verbal exchange in order to obtain information or information on facts of the behaviors, opinions or beliefs that meet the stated purpose that the sponsor of the investigation has set himself in his research hypotheses. They are supplemented by some accepted techniques in social sciences.

\section{Delimitation of work}

We could not have the idea to address this subject exhaustively. This is how we delimit it in time and space. To do this the spatial delimitation is on the Democratic Republic of Congo, more precisely in the city of Kinshasa province and the temporal delimitation covers the intervention going from 1990 to 2014 because it is during this period that we knew the principal causes of poverty (structural causes and cyclical causes) as well as some reforms improving the macroeconomic framework.

\section{Internal structure of the study}

We divided the work into two parts. The first part explains the meaning of general notions about microfinance. The second part describes the importance and the diagnostic sense of microfinance. It explains the different structures that govern microfinance and we will finally discuss the effectiveness of this microfinance.

\section{Part I. General considerations and the diagnostic of microfinance}

1.1. General considerations and the diagnostic of microfinance

Microfinance systems are structures offering basic financial services (savings / credit) and more elaborate (insurance) to a segment of the population excluded from traditional financial circuits such as the population in the Democratic Republic of Congo. The oldest and best known element of microfinance is microcredit, which consists of short-term short-term loans [Armendariz and Mordach, 2005,pp. 57-58]. Over the last decade, microfinance has attracted growing interest from political and economic decision-makers as well as academia [Morduch, 1999, pp. 42-43]. Microfinance has existed in various forms for several years. But it has really been organized for only forty years. By the 1960s and 1970s, low-interest loan programs had emerged, the principle of which was taken up by the banks of the poor in their present forms.

The idea of GRAMEN BANK came from Muhammad Yunus when he lent from his pocket the equivalent of $\$ 26$ to 42 women exploited as chair rammers in his own country Bangladesh[Yunus, 2006, pp. 37-38]. If, microfinance and funding NGOs are designated as devices to offer very small credits or "micro credits" to very poor families to help them conduct productive or income generating activities allowing them to develop their very small businesses; It should also be noted that they included a wider range of services (credit, savings, insurance, money transfer, etc.) and a larger clientele as well. The question must be answered: "What is happening in the Democratic Republic of Congo?" In the Democratic Republic of Congo, people, especially rural and peri-urban populations, are living in particularly difficult conditions. These have particularly deteriorated in recent years, with the looting of 1991 and 1993, the war of 1996 and 1998, the economic crisis and political and institutional instability. However, the extent of the problems linked to political and institutional instability, looting and armed conflict can not be the only factors explaining the constant deterioration of living conditions in rural areas and peri-urban centers. There are, in fact, a multitude of causes of a more structural nature that make the situation of rural and peri-urban populations extremely precarious. On this, it will be necessary first to review the situation of poverty in the Democratic Republic of Congo, the causes of the said poverty, the set of projects and activities planned to carry out the fight against poverty as well as the actors of development of the National Microfinance Program[UNDP, Consolidated Annual Progress Report, May 2012, pp.115-116]. Then we will make the history of the microfinance sector in the Democratic Republic of Congo and explain the main causes of its growth, then briefly describe the various formal and informal actors involved. Finally, we will address the concern for the contribution of microfinance NGOs in the fight against poverty in this country. All these elements will be used for the elaboration of the present chapter, and will propose new solutions.

\subsection{State of microfinance and the situation of poverty in the DR Congo}

Before examining the main explanatory factors of poverty in the Democratic Republic of Congo and presenting the national strategies to combat poverty, we considered it useful to devote the first part of this section to analyzing the situation of poverty in this country. We know that the poverty is an evil that must be eradicated wherever it is in a rich or poor country[ Yunus M., 2006, pp. 53-54]. Poverty is not a myth in the Democratic Republic of Congo given the 
inability of a large proportion of the population in both rural and urban areas to meet the most basic needs (food, water, medical care, housing)

Table 1. Macroeconomic data

\begin{tabular}{|l|l|}
\hline Population (millions) & 71 \\
\hline Area (thousands km2) & 2345 \\
\hline Density (inhabitants / km2) & 30,2 \\
\hline Population growth rate (\%) & 3,1 (est.) \\
\hline Literacy rate (\%) & 67,2 \\
\hline Nominal GDP (billion USD) & 8,7 \\
\hline GDP / capita (USD) & $2009)$ \\
\hline Share of urban population (\%) & 122 (est.2009) \\
\hline Annual rate of inflation (\%) & $34(2008)$ \\
\hline Population below the poverty line & 2 (est. 2009) \\
\hline
\end{tabular}

Source: Elaborate by the author on the basis of the data of the CIA, the World Factbook, 2010

Despite its immense natural resources, the Democratic Republic of Congo is one of the poorest countries in the world, where the years of war killed the country by destroying the few infrastructure and productive activities that were there. People live in deplorable economic and health conditions, particularly in the eastern parts of the country where armed rebel groups still operate. Social indicators are so low that it is virtually impossible for the country to achieve one of the MDGs (Millennium Development Goals). Access to water and sanitation accounts for only 22 and 9 percent of the total population respectively, with large disparities between regions and between rural and urban areas[Epstein K. and Smith G., 2007, 38-41].

Nearly $80 \%$ of the Congolese population survive the limit of human dignity, with less than one (1) Usd per person per day and less than $20 \%$ of inhabitants have regular access to electricity. According to the national report on human development, the Democratic Republic of Congo is currently ranked 187th out of 187[Nair A. et Von Pischke J. D. 2007, pp.617-629] with a per capita national income at purchasing power parity of 705 dollars per year. The Democratic Republic of Congo would also be the country that would shelter the most child soldiers in the world.

The human rights violations during the war, in particular of children and women, had very deep repercussions within the populations. In many provinces, anti-personnel mines still prevent people from working the land ... Regional disparities are very strong. The populations of the East of the country lived on average with 32 dollars per year and per inhabitant while those of the South had 138 dollars and those of the province of Kinshasa, of 323 dollars, three times more than in the East. Poverty is manifested by malnutrition that affects between 30 and 50 percent of women and children. A total of 16 million people are food insecure. Regarding the food situation, while the Democratic Republic of Congo had never experienced a food crisis in the 30 years following its accession to independence in 1960, UNDP statistics show that in 1990 and 2003 the number of people suffering from malnutrition more than doubled, from 17 million (32\% of the population) to 38.5 million people (71\% of the population).

\subsection{Diagnosis on microfinance in the DRC}

Our objective in addressing this point is not to re-present the details of a situation known to all, namely insufficient banking coverage of the country and the distortions existing in the provincial establishment of the counters of commercial banks and other financial institutions, but rather to reflect on the main themes on which our analysis will be based and the identification of priorities for possible intervention.

\subsubsection{Government devices}

The bankruptcy of commercial banks, mainly those controlled by the state and the exhaustion of private capital, can be explained by a situation inherited from several decades. Indeed, in its note of presentation of the economic situation of the country, the central bank of Congo already revealed in October 2003 that between 1995 and 2000, the GNP saw a fall of $40 \%$ and the country lived under a regime of hyperinflation with an annual rate of $62 \%$ of the monetary depreciation [Schmidt R.H., 2010, pp.99-136]. This situation led to the significant reduction of the activities of the non-banking Financial Institutions and the slowing down or even the disappearance of the activity of the structures of proximity as regards collection of savings and credit distribution. These findings have made it a priority to promote alternative financing structures capable of:

- Ensure the mobilization of small savings and credit in poor rural and urban areas;

- Create conditions for the gradual insertion of the informal sector into the modern national economy. To achieve these objectives, the government's efforts have relied more on relative political and economic stability through the control of inflation, the respect of expenditure initiation procedures and the liberalization of interest rates.

These measures had the benefit of:

- Monitoring and reducing inflation from $511 \%$ in 2000 to $5.7 \%$ in 2003, 
- An appreciation of the national currency against the main currencies, estimated at $12 \%$, and an economic growth evaluated at $3.4 \%$ of the GDP in 2003[Bornstein D. , 2011, pp. 28-29].

These various indicators have favored the emergence of the microfinance sector, which can effectively support economic growth and the creation of new jobs.

\subsubsection{The legal and regulatory framework of the microfinance sector}

Before independence, by the decree of 24 March 1956, the legislator had organized the creation and operation of "indigenous cooperative societies" whose object was to promote, through the implementation of cooperative principles, economic and social interests. of their members. Savings and credit cooperatives (SACCOs) were also subject to this decree and placed under the supervision of the provincial governor. At the institutional level, the Ministry of Finance provides legal oversight and overall responsibility for the Democratic Republic of Congo financial sector. It is also the guardianship of the Central Bank of Congo. The central bank is the regulatory and supervisory authority of credit institutions, MFIs and other financial intermediaries. And this according to Article 6 of Law No. 005: 2002 of May 7, 2002 on the constitution, organization and operation of the Central Bank of Congo (CBC). The law applicable to savings and credit cooperatives (COOPEC) defines a set of duties and obligations with a view in particular to the protection of the saver but also provides tax exemptions to encourage activity. It imposes no minimum capital on savings and credit cooperatives. This specific law for savings and credit cooperatives deserves adaptation in the interests of regulatory coherence. The current regulatory framework includes a law on savings cooperatives and credits (Law No. $002 / 2002$ of 2/2/2002), a law on the activity and supervision of credit institutions (Law No. 003/2002 of 2/2/2002) and amended instruction $n 1$ of 18/12/2005 relating to activity and control. Note however that this instruction of the Central Bank of Congo does not regulate the matters falling within the field of the law and may have among other disadvantages:

- Inaccurate identification of microfinance institutions: to understand their identification, education focuses on defining microfinance institutions based on their economic function;

- confusion between banking and microfinance operations leading to uncontrolled competition between credit institutions (such as savings and credit cooperatives) and microfinance institutions;

- an unfavorable tax system that does not take into account their character as structures responsible for poverty reduction.

Finally, let us say that these various provisions are, by themselves, insufficient and do not allow to favor the emergence of a solid and sustainable microfinance sector. Hence, they must be well structured and reorganized to fulfill their function of reducing poverty.

General presentation of the legal and regulatory framework of financial institutions in DRC

Table $\mathbf{N}^{\circ} \mathbf{2}$

\begin{tabular}{|c|c|c|c|c|c|c|c|}
\hline $\begin{array}{l}\text { Descript } \\
\text { ion }\end{array}$ & Banks & $\begin{array}{l}\text { Financing } \\
\text { companies }\end{array}$ & $\begin{array}{l}\text { Saving } \\
\text { s and } \\
\text { Credit } \\
\text { Coope } \\
\text { ratives } \\
\text { (" } \\
\text { coopec } \\
\text { ") }\end{array}$ & $\begin{array}{l}\text { Microfin } \\
\text { ance } \\
\text { compani } \\
\text { es }\end{array}$ & $\begin{array}{l}\text { Microfina } \\
\text { nce } \\
\text { company, } \\
\text { level } 2\end{array}$ & $\begin{array}{l}\text { Microfin } \\
\text { ance } \\
\text { compan } \\
y \text {, level } \\
1\end{array}$ & $\begin{array}{l}\text { Non-profit } \\
\text { organization } \\
\text { for the } \\
\text { promotion } \\
\text { of the } \\
\text { "social" } \\
\text { loan }\end{array}$ \\
\hline $\begin{array}{l}\text { Legal } \\
\text { form }\end{array}$ & $\begin{array}{l}\text { Limited } \\
\text { Liability } \\
\text { Joint } \\
\text { Stock } \\
\text { Compan } \\
\text { y }\end{array}$ & $\begin{array}{l}\text { Commerci } \\
\text { al } \\
\text { company, } \\
\text { format to } \\
\text { study with } \\
\text { the } \\
\text { Central } \\
\text { Bank of } \\
\text { Congo }\end{array}$ & $\begin{array}{l}\text { Coope } \\
\text { rative }\end{array}$ & $\begin{array}{l}\text { Limited } \\
\text { Liabilit } \\
\text { y Joint } \\
\text { Stock } \\
\text { Compa } \\
\text { ny }\end{array}$ & $\begin{array}{l}\text { Free, but } \\
\text { compatible } \\
\text { rights of } \\
\text { persons }\end{array}$ & $\begin{array}{l}\text { must be } \\
\text { with the } \\
\text { f legal }\end{array}$ & $\begin{array}{l}\text { All forms of } \\
\text { non-profit } \\
\text { organization } \\
\text { s formed by } \\
\text { members }\end{array}$ \\
\hline $\begin{array}{l}\text { Authoriz } \\
\text { ed } \\
\text { activitie } \\
\text { s }\end{array}$ & $\begin{array}{l}\text { Savings, } \\
\text { credit, } \\
\text { internati } \\
\text { onal and } \\
\text { domesti } \\
\text { c } \\
\text { transfers } \\
\text {, etc. }\end{array}$ & $\begin{array}{l}\text { Credit, } \\
\text { other } \\
\text { possible } \\
\text { activities, } \\
\text { no savings }\end{array}$ & $\begin{array}{l}\text { Savings } \\
\text { credit }\end{array}$ & and & $\begin{array}{l}\text { Credit } \\
\text { (savings } \\
\text { only with } \\
\text { special } \\
\text { authorizati } \\
\text { on from } \\
\text { the } \\
\text { Central } \\
\text { Bank of } \\
\text { Congo) }\end{array}$ & $\begin{array}{l}\text { Credit } \\
\text { only } \\
\text { (max } \\
\text { USD } \\
250 \text { per } \\
\text { person } / \\
\text { cycle) }\end{array}$ & $\begin{array}{l}\text { Social credit } \\
\text { to their } \\
\text { members }\end{array}$ \\
\hline $\begin{array}{l}\text { Minimu } \\
\mathrm{m} \text { level } \\
\text { of } \\
\text { capital }\end{array}$ & $\begin{array}{l}1,5 \\
\text { million } \\
\text { USD }\end{array}$ & $\begin{array}{l}\text { To study } \\
\text { with the } \\
\text { Central } \\
\text { Bank of } \\
\text { Congo }\end{array}$ & No & $\begin{array}{l}100000 \\
\text { USD }\end{array}$ & $\begin{array}{ll}50 & 000 \\
\text { USD } & \end{array}$ & $\begin{array}{l}15000 \\
\text { USD }\end{array}$ & No \\
\hline
\end{tabular}

Source : Isern, J. \& Ali. : Diagnosis of the regulatory and political framework on access to financial services in the Democratic Republic of Congo (DRC), CGAP, 2007 


\subsection{Evolution of the microfinance in the DRC}

Generally, it is admitted that the history of microfinance in the Democratic Republic of Congo dates back to colonization with the decree-law of the sovereign king of the Belgians of March 24, 1956 on the creation and operation of indigenous cooperative societies and even a little earlier with paysannats. From this decree, one can retain the creation of the first cooperatives directed by the natives of the Belgian Congo. Thus, this history of the system of decentralized financing in Democratic Republic of Congo was forged around the three successive waves each having its own characteristics[Bateman M. (2011), pp. 124-125] .

\subsubsection{The first wave: colonization by the decree of March 24, 1956}

This first phase of the history of local financing brings together the different paysannats and agricultural cooperatives created by colonization to increase the production of raw materials for the industry of the metropolis. These include cooperatives and paysannats around certain products including cotton, oil palm, rubber ... The cooperatives of this first wave were financed by seven financial organizations approved under the decree-law of March 24, 1956 to grant loans to indigenous cooperatives. These are the following institutions:

- Belgian Bank of Congo,

- Congolese Bank Corporation,

- Belgian Bank of Africa, Kredietbank Congo,

- National Bank for Trade and Industry,

- National Federation of Christian Cooperatives of Belgium,

- Caisse d'Epargne.

To avoid disorder, each approved institution had its territorial limits of intervention in the loan distribution:

Table $N^{\circ}$ 3. List of Agencies and Provinces of intervention

\begin{tabular}{|c|c|}
\hline ORGANIZATIONS & PROVINCES OF INTERVENTION \\
\hline Belgian Congo Bank & $\begin{array}{l}\text { Leopoldville, Ecuador, Kasai, Katanga, Kivu and } \\
\text { Orientale }\end{array}$ \\
\hline Congolese Bank Corporation & Leopoldville, Katanga, Kivu, Orientale \\
\hline Belgian Bank of Africa & $\begin{array}{lll}\text { Leopoldville, } & \text { Ecuador, } & \text { Katanga, } \\
\text { Kivu, } & \\
\text { Orientale } & \end{array}$ \\
\hline Kriedtbank Congo & Leopoldville, Katanga, Kivu, Orientale \\
\hline National Bank for Trade and Industry & Leopoldville \\
\hline $\begin{array}{l}\text { Federation of Christian Cooperatives of } \\
\text { Belgium }\end{array}$ & Leopoldville \\
\hline Checkout Saving & $\begin{array}{r}\text { Leopoldville, } \quad \text { Ecuador, } \\
\text { Katanga, Orientale }\end{array}$ \\
\hline
\end{tabular}

Source: Kikata Pubu Mayuma N. Op.cit., p.2

This territorial distribution in favor of the financial institutions had the advantage of better distributing the interventions and better distributing the credits. It should be noted that no financial cooperative was created during this period by the Congolese natives.

\subsubsection{The second wave: independence (1960 to 1990)}

It is aware of this second wave that the Congolese natives were able to constitute the first purely financial cooperatives. Despite the lack of knowledge and experience in cooperative management, large local financial institutions have emerged. This is particularly the case of Caisse Populaire Credit Luymas / CBCO, Cooperative Savings and Credit Community Evangelical Africa in Congo (COOCEC ECAC), Cooperative Savings and Credit Community Evangelical Congo (COOCEC CEC), Cooperative Savings and Credit Basankusu, COOPEC Tujenge, COOPEC Nyawera ...

During this second period, two major households formed the basis for the development of cooperatives in DR Congo:

- the Kinshasa focus (which includes the city of Kinshasa, the Provinces of Bandundu, Bas-Congo of Ecuador),

- the second home, that of Kivu, which includes the rest of the Republic (North Kivu, South Kivu, Maniema, Katanga and Province Orientale).

\subsubsection{The third wave: from 1990 to today.}

With the democratization of the country in the 1990s, there was a liberalization of the economy on the one hand and the financial sector on the other. In addition, the 1997 World Microfinance Summit in New York saw the emergence of a particular type of microfinance community finance. Thus, alongside savings and credit cooperatives, with their own history and wellsupplied history, microfinance institutions are developing, also with their own peculiarities: the proximity of the activity, the access of the poor to financial services and the liberalization of the interest rate (the key rate of the Central Bank remains the reference rate par excellence [World Bank, World Development Report: Combating Poverty, 2009, pp. 206-210]. 


\section{Part II. New horizons for the expansion of the microfinance sector in the DRC}

The financial and economic situation of the Democratic Republic of Congo after the 1970s has experienced some deterioration following the instability of the macroeconomic framework. It is only at the end of the second millennium that a turnaround will bring about a slight improvement in this framework. Indeed, it is clear that the improvement in the economic situation of the Democratic Republic of Congo in recent years is partly linked to the implementation of economic reforms aimed at restoring the major macroeconomic balances. However, important as they may be, these reforms have proved insufficient to reduce the incidence of poverty in rural and urban areas. Despite economic recovery efforts, poverty in cities and the countryside has not declined. On the contrary, poverty in general has increased. Successful development depends not only on productivity growth and GDP per capita. Indeed, it requires growth to be inclusive, to improve the quality of life and to contribute to the advancement of human development. The latter favors the effective implementation of the national microfinance policy.

However, these actors in the sector must share a common vision and commit to translate it into concrete and concerted actions in order to enable the sector to control its growth and overcome the crises and malfunctions that generally occur during its phase. expansion. Thus, A National Development Strategy, whose guidance necessarily applies to the specificities and roles of different sectors and takes them into account, must shape these policies so as to achieve the objectives of growth and human development. This chapter discusses the different political, financial and social strategies that can influence, complement and regulate microfinance activities to combat poverty in the Democratic Republic of Congo. The results of the survey of microfinance institutions and savings and credit cooperatives in Kinshasa enabled us to identify the strengths and opportunities for the development of the sector as well as the weaknesses and threats of this sector.

In most cases, microfinance institutions in Congo come from NGOs and to this end, they associate the population in the analysis of the problems of the sector; consequently, they are closer to this poor population to whom they offer financial services, even if they are unable to meet the most immediate needs of this population by their action mainly to women. It should be noted that they establish and revive the financial culture and public confidence in financial institutions. The diversity of financial institutions and / or having a microfinance component (savings and credit) in their activities in the most remote corners of the country has the advantage of creating income-generating activities and thus the creation of employment . As a result, the relative stability of the macroeconomic environment observed over the past decade is a major asset that favors the entry of international practitioners into the sector and thus stimulates competition. A strong political will to develop the sector and put an end to practices that hinder its growth, which leads to the infatuation with microfinance by national and international practitioners, it also lives an important local dynamic based on a long cooperative tradition, in spite of the different crises[Waterfield, 2010, pp. 35-37]. The weaknesses and threats to the expansion of the microfinance sector in the Democratic Republic of Congo show us that since the wave of democratization of the country and the introduction of political multipartism in the 1990s, the Congolese financial sector has been mistrustful of the population. To the unpopular measures we can quote among others:

- Lack of funding capacity at the level of structures, donors and the State, the lack of consultation and synergy between the donors and the various stakeholders in the sector thus hindering the professionalization and sustainability of the project. provides financial services;

- the mismatch between supply and demand for financial services and the low diversity of financial products offered to the population thus rendering the action of the institutions ineffective,

- the lack of interaction between practitioners in the sector, the atomicity of MFIs and their inability to prevail in the market does not favor the emergence of an efficient decentralized financial sector;

- low equity, the lack of working capital does not allow the diversification of products offered to customers;

- the absence of a specific legal framework for the microfinance sector, as well as the lack of a national policy in this area, can not be used to channel the action of international donors.

On the other hand, threats to the main threats to the development of the sector are related to the economic, political, institutional and social environment. Among these threats we can mention:

- Insufficient concentration in the process of developing the national micro finance strategy, in the process of developing the specific law applicable to MFIs, and a lack of support for the sector could hinder the development of a micro financial sector transparent, effective and sustainable;

- The relevance of armed conflict in the east of the country is undoubtedly a threat to peace, a prerequisite for any economic development.

- The lack of a culture of savings and credit and the mistrust of the population could also hinder the development of the microfinance sector;

The lack of relationship between microfinance and the promotion of private entrepreneurship would weaken the financing of small and medium-sized enterprises;

- Insufficient synergy between the actors involved (COOPECs and MFIs, banks, development NGOs, donors) and the low level of collaboration between them as well as the lack of visibility on the possible complementarities and coherence with the activities of other partners, lead to risks of duplication and waste of resources[UNDP, Consolidated Annual Progress Report, 57-58] . 


\subsection{Institutional Framework for Implementation, Monitoring and Evaluation 2.2.1. Immediate actions}

Immediate action means those that must be undertaken or carried out urgently. Financial services for the poor pose policy and program design issues. Overall, credits or savings are small amounts and this situation increases transaction costs per unit of money lent. In addition, the target population is poor, illiterate and / or unable to count, which complicates the maintenance of records and their processing. For the Democratic Republic of Congo, the actions must relate to:

a) Professionalisation and sustainability of the sector

In this context, several options can be envisaged, among others:

- Encourage the grouping of structures into viable and strong professional associations;

- Promote access to training, exchange of experiences for all viable practitioners;

- Contribute to a greater structuring of the profession and strengthen the participation of institutions in the design and implementation of programs for the sector.

b) Promote the emergence and development of Microfinance Institutions in National capitals

- Subsidize the creation of domestically owned structures in the sector;

- Encourage the viability and sustainability of MFIs and the growth of a diversified service offering;

- Improve the management capacity of MFIs for good governance and the development of national skills.

To achieve these objectives, it is necessary to create a framework for consultation so that microfinance institutions (IMF) evolve in synergy and that customer information is made available to all institutions to identify bad customers.

\subsubsection{Medium and long-term actions}

The second phase of the Growth and Poverty Reduction Strategy Paper (PRGSP II) was initiated in the wake of the completion of the Heavily Indebted Poor Countries (HIPC) Initiative Completion Point. The government has shown its willingness to leave an emergency logic (on which the GPRSP I is based) for a phase of growth and development. Pending the preparation of a new long-term vision based on the 50 years of existence as an independent state, this strategy is based on a vision of a "Society of Hope", able to hoist the Democratic Republic of the Congo to the human development level of middle-income countries and converge towards the Millennium Development Goals (MDGs). To ensure long-term stability and support strong growth, this strategy, with a five-year time horizon, is based on four (4) pillars, each with clear strategic priorities and priority actions for their implementation:

- Strengthen governance and peace;

- Diversify the economy, accelerate growth and promote employment;

- Improve access to basic social services and strengthen human capital;

- Protect the environment and fight against climate change.

Once the establishment of a national strategy for microfinance, professionalization and sustainability of the activities of the said sector the opportunity for the emergence and / or development of microfinance institutions (MFIs) with capital national and possible. As a result, several other actions can be carried out in the medium and long term as needed. Types of Micro Finance Institution and Management Proposal.

To identify typical microfinance institutions, the following criteria can be used:

- Importance of the loan portfolio distributed,

- Number of clients reached by the loan,

- Loan portfolio late;

- Level of administrative and financial organization.

In the case of the Democratic Republic of Congo, only MFIs with foreign capital: FINCA RD CONGO, HOPE RD CONGO, SOCODEVI GROUP, fulfill the above-mentioned criteria. These structures offer stability and effective working methods that can enable them to compete with other international institutions. As for the others, they still seek to position themselves with respect to, for example, compliance with prudential ratio regulations ie (late portfolio, coverage rate, etc.). However, as the list of goals for a better decentralized financial sector indicates, the challenge is to identify where to start. This is to analyze the comparative advantages of the stakeholders and identify which of the priorities for a sequential and harmonious development of the sector that is to say that a plan must be defined. action plan that reflects the institution's mission to understand what needs to be done and what can be achieved.

\subsection{As a recommendation}

On the basis of the above elements, the recommendations are as follows:

- Support the development of the national micro finance policy;

- Setting up a structure to provide technical and financial support to national practitioners in the sector, setting up an action plan and a co-financing research budget. 
- Strengthening the capacity of intermediate structures is one of the priorities for the survival of the microfinance sector in Democratic Republic of Congo. As such, it is useful to say that collaboration with other international stakeholders such as UNDP, GTZ, USAID, FAO, SOS FAIM and CIDA ..... is of paramount importance.

- Establishment of an enabling framework for discussions and development of a national policy will provide a general framework and guide the development of the sector.

- Strengthening the supervisory structures and professional associations, ie the existence of strong and dynamic professional associations, will be a success on which the international partners could rely in the popularization of their methods and strategies of work. All this will mark the consolidation and formalization of the microfinance sector in Democratic Republic of Congo.

- That the different types of microfinance funds are specifically named for more details and that they are called microfinance associations for better categorization. And this with reference to the decree of 1921. It would be convenient to call them civil societies.

- That the Bank be vigilant in accepting institutions that operate in the field of microcredit without going through it and that an agreement is always signed with it for an efficient periodicity likely to produce the impact of share and 'other.

- That the requirement of the Central Bank of Congo (CBC) for the transmission of monthly reports be reviewed so that only one annual report is required.

- Compared to the services recognized by MFIs, they not only collect the savings of members, but also of their clients.

- That the legal status of microfinance funds and microfinance companies be clarified.

- That the requirement for a criminal record check be revised to replace it only by the certificate of good life and morals.

\section{CONCLUSION}

At the end of this work which sanctions the end of our studies of the cycle of graduat, we found it good to carry out a study on microfinance NGOs in the process of the fight against poverty in the Democratic Republic of Congo. It was specifically to understand the contribution of microfinance in the process of the fight against poverty in the Democratic Republic of Congo. This concern is based on the fact that the working classes in rural or urban areas are characterized by massive poverty and face many problems such as undernourishment, vulnerability and low investment in human capital. These popular classes traditionally do not have access to bank loans. The credits they need, usually between 5000 and 10,000 Usd, are too small to be economically viable for conventional banks. Most bankers consider microentrepreneurs to be far too risky because of their inability to produce collateral, the way they manage their accounts, and their informal status. This popular class mainly uses the endogenous sector. The sources of credit available to micro-entrepreneurs are thus limited to family members, traders and other informal lenders who, in general, charge extremely high interest rates. At the beginning of this work, we have hypothesised that Micro Finance is one of the most effective weapons in the fight against poverty and thanks to it, an integral development is possible. We delimited our study at the level of the Democratic Republic of Congo, more precisely in the city of Kinshasa province during the period from 1990 to 2011 and we used the techniques and methods described in the introduction of this work to better conduct our investigations. We have subdivided our work into three chapters in order to achieve it correctly. So the first part identifies the concepts and theories related to microfinance. It should be noted that microfinance refers to the mechanisms by which very small families can be offered microloans to help them conduct productive or income-generating activities that enable them to develop their very small businesses.

With the time and development of this particular sector of finance around the world, including in developed countries, microfinance has expanded to include a wider range of services (credit, savings, insurance, credit transfer). money etc.) and a wider clientele as well. In this sense, microfinance is no longer limited today to the granting of microcredit to the poor but to the provision of a set of financial products to all those who are excluded from the conventional or formal financial system. The second explicitly addressed the diagnosis of microfinance in the Democratic Republic of Congo. With that, we went through the situation of poverty, these main causes and the different projects of fight against the poverty as well as the contribution of the NGOs of microfinance. In addition, this last part constitutes the base of our work insofar as it proposes to define a sectorial policy in relation with the microfinance and the NGOs of financing. We first relied on the results of the survey of micro-finance institutions and savings and credit cooperatives operating in Kinshasa. Then we proposed new sectoral policy horizons related to microfinance and NGOs funding through the GPRSP and PASMIF and finally we have proposed solutions in the form of action in the short, medium and long term.

Since poverty is a complex phenomenon that has among its many manifestations the limitation of access to goods, services and assets that it imposes on people who are hit by it, microcredit can play a role in the financing of its struggle. The poor need leverage for their inclusion in markets and other forms of social contracts. The merit of microfinance results from the fact that it acts at the level where poverty has its most obvious effects: the household. It makes it possible to respond directly to the financing needs of consumption and / or the investment of the poor household. The generalization of this mode of financial intermediation in a country where poverty is creeping however supposes the establishment of appropriate mechanisms to ensure its sustainability. These are mechanisms for risk management. By facilitating access to financial services for private households, microfinance opens up new opportunities for access, services and assets to households that would be deprived of them. It is necessary to understand the nature, outlines and limits of microfinance. This is to avoid doing what she can not do and getting the best she can offer. It also requires sweeping away myths such as the insolvency of the poor and the dependence of MFIs on donor funding to build a financial sector that views the poor as legitimate clients and in which MFIs are mainly financed by deposits and investments rather than by the state and donors. Thus, it is undoubtedly to say that microfinance is an indispensable tool in the process of the fight against poverty in the Democratic Republic of Congo. 


\section{BIBLIOGRAPHY}

[1].Bateman M. (2011), « Over-Indebtedness and Market Forces », CGAP Microfinance Blog, 11 février.

[2].Berndorff J. et Lungert V. (2010), « Ein Visionär scheitert », Natur und kosmos, novembre.

[3].Bornstein D. (2011), « Grameen Bank and the Public Good », New York Times, 24 mars.

[4].Chen G., Rasmussen S., Reille X. et Rozas D. (2010), «Indian Microfinance Goes Public: the SKS Initial Public Offering », CGAP Focus Note, $\mathrm{n}^{\circ} 65$.

[5].DB Research (2007), « Microfinance: an Emerging Investment Opportunity », Frankfurt: Deutsche Bank.

[6].Epstein K. et Smith G. (2007), «The Ugly Side of Microlending », Business Week, 12 décembre. Disponible sur le site :www.businessweek.com/stories/2007-12-12/theugly-side-of-microlending.

[7].Levine R. (2005), «Finance and Growth: Theory and Evidence », in Aghion P. et Durlauf S. (éd.), Handbook of Economic Growth, vol. 1, pp. 865-934.

[8].Morduch J. (2000), « The Microfinance Schism », World Development, vol. 28, pp. 617629.

[9].Nair A. et Von Pischke J. D. (2007), « Commercial Banks and Financial Access », in Barr M. S. et al. (éd), Building Inclusive Financial Systems: a Framework for Financial Access, Brookings, pp. 89-116.

[10]. PCH (ProCredit Holding AG) (2012), Annual Report 2011.

[11]. Rhyne E. (2001), Mainstreaming Microfinance: How Lending to the Poor Began, Grew and Came of Age in Bolivia, West Hartford, CT (Kumarian Press).

[12]. Roodman D. (2012), Due Diligence: an Impertinent Inquiry into Microfinance, Center for Global Development.

[13]. Rosenberg R. (2007), « CGAP Reflections on the Compartamos Initial Public Offering: a Case Study on Microfinance Interest Rates and Profits », CGAP Focus Note, ${ }^{\circ} 42$.

[14]. Schmidt R. H. (2010), « Microfinance, Commercialization and Ethics », Poverty and Public Policy, vol. 2, pp. 99137. UNDP, Consolidated Annual Progress Report on the "Microfinance Sector Support Program, Phase II", May 2012.

[15]. Unité de Pilotage du Processus d'Elaboration du DSCRP (UPPE-SRP), « Document de la stratégie de croissance et de réduction de la pauvreté », Kinshasa, 2006

[16]. Waterfield C. (2010), « Has the Microfinance Market Come of Age?», CGAP Microfinance Blog, 18 octobre.

[17]. Woller G., Dunford C. et Woodworth W. (1999), « Where to Microfinance? », International Journal of Economic Development, vol. $1, \mathrm{n}^{\circ} 1$.

[18]. World Bank, World Development Report: Combating Poverty, 2009.

[19]. Yunus M. (2006-2007), « Poverty Is a Threat to Peace », discours de réception du prix Nobel de la paix, prononcé le 10 décembre 2006, in Yunus M., Creating a World without Poverty, Public Affairs, épilogue.

\section{MICROFINANCEMENT ET LUTTE CONTRE LA PAUVRETÉ EN RÉPUBLIQUE DÉMOCRATIQUE DU CONGO \\ Résumé}

En étudiant à la fois les cas congolais et camerounais, cet article montre qu'à côté d'une certaine standardisation, la microfinance tend à des modes d'appropriation très caractéristiques. Les auteurs considèrent le rôle des États comme des "vecteurs" du mot "microfinance". Ils remettent en question la capacité et la liberté des organisations et des autorités locales à mettre en œuvre des programmes de microfinance. La première partie du document souligne le concept normatif, à savoir la "microfinance". Les deuxième et troisième sections traitent de la circulation du terme et de la production de pratiques en République démocratique du Congo et au Cameroun. Il conclut que, malgré la mise en application finale des pratiques et des normes sociales, la microfinance doit s'acclimater à des pratiques sociales, politiques et même religieuses divergentes.

Mots-clés: microcrédit - microfinance - crise financière Code JEL: G 29 - 016 - F 30 